\title{
Manning's roughness coefficient for the Doce River
}

\author{
Coeficiente de rugosidade de Manning para o Rio Doce
}

\author{
Emmanuel Kennedy da Costa Teixeira', Márcia Maria Lara Pinto Coelho ${ }^{2}$, Eber José de Andrade Pinto ${ }^{2}$, \\ Jéssica Guimarães Diniz ${ }^{1}$ and Aloysio Portugal Maia Saliba ${ }^{2}$ \\ ${ }^{1}$ Universidade Federal de São João del-Rei, Ouro Branco, MG, Brasil \\ ${ }^{2}$ Universidade Federal Minas Gerais, Belo Horizonte, MG, Brasil \\ E-mails: emmanuel.teixeira@ufsj.edu.br (EKCT), lara@ehr.ufmg.br (MMLPC), eber.andrade@cprm.gov.br (EJAP), \\ jessica.guimaraes.diniz@gmail.com (JGD),asaliba@ehr.ufmg.br (APMS)
}

Received: January 31, 2018 - Revised: July 25, 2018 - Accepted: September 11, 2018

\begin{abstract}
The Manning's roughness coefficient is used for various hydraulic modeling. However, the decision on what value to adopt is a complex task, especially when dealing with natural water courses due to the various factors that affect this coefficient. For this reason, most of the studies carried out on the subject adopt a local approach, such as this proposal for the Doce River. Due to the regional importance of this river in Brazil, the objective of this article was to estimate the roughness coefficient of Manning along the river, in order to aid in hydraulic simulations, as well as to discuss the uncertainties and variations associated with this value. For this purpose, information on flow rates and water depths were collected at river flow stations along the river. With this information, the coefficients were calculated using the Manning equation, using the software Canal, and their space-time variations were observed. In addition, it was observed that the uncertainties in flow and depth measurements affect the value of the Manning coefficient in the case studied.
\end{abstract}

Keywords: Uncertainties in the roughness coefficient; Hydraulic modeling; Monte Carlo simulation.

\section{RESUMO}

O coeficiente de rugosidade Manning é utilizado em várias modelagens hidráulicas. Entretanto, a decisão sobre qual valor será adotado é uma tarefa complexa, principalmente se tratando de cursos d'água naturais, devido aos vários fatores que afetam esse coeficiente. Por isso, na maioria dos estudos realizados sobre o tema se adota uma abordagem local, como a proposta para o Rio Doce. Devido à importância regional deste rio no Brasil, o objetivo deste artigo foi estimar a rugosidade de Manning ao longo do Rio Doce, de forma a auxiliar em simulações hidráulicas, e também discutir as incertezas e as variações associadas a esse valor. Para isso, foram levantadas informações de vazões e profundidades da água em estações fluviométricas ao longo do rio. De posse dessas informações, calcularam-se os referidos coeficientes utilizando-se a equação de Manning, sendo que para isso utilizou-se o softwware Canal, e foram observadas suas variações espaço-temporal. Além disso, foi observado como as incertezas nas medições de vazões e de profundidades afetam o valor do coeficiente de Manning no caso estudado.

Palavras-chave: Incertezas no coeficiente de rugosidade; Modelagem hidráulica; Simulação de Monte Carlo. 


\section{INTRODUCTION}

One of the most widely used equations for calculating the flow rate in open channel in uniform flow is Manning's (PARSAIE et al., 2017). This expression defines the balance between motive force (gravity) and the flow resistance, being this resistance expressed through Manning's roughness coefficient " $n$ ".

This roughness coefficient is commonly used in numerical modelings to study rivers hydraulic behavior (KIM et al., 2013), as well as to generate simulations in order to construct flooding maps, hydraulic structures projects, like bridges and dams, among other applications. Kopecki, Schneider and Tuhtan (2017) presents that regardless the dimensionality $(1 \mathrm{D}, 2 \mathrm{D}$, etc) of the hydraulic model used, all of them must be calibrated adjusting one value to the Manning's coefficient, in order to reproduce the water surface elevations that have a close value to the field measurements.

However, the adoption of an appropriate coefficient can be challenging, involving practical experience and individual and local judgements, which could result in obtaining different values in the analysis of the same channel (ZINK; JENNINGS, 2014; AYVAZ, 2013). This happens due to the fact that the roughness coefficient has its value influenced by numerous factors, since the flow of the rivers happens in diverse and complex conditions (FARD; HEIDARNEJAD; ZOHRABI, 2013; CALO et al., 2013). Chow (1959) presents that various interfering factors can affect the coefficient, such as the surface roughness, channel irregularities and alignment, vegetation effects, changes on the channel bed geomorphology due to deposit or degradation of materials and the transport of suspended and/or bottom sediments. In addition, the author presents that the roughness coefficient varies in the cross section due to the variation in water levels, the lower the water depth, the higher the coefficient value, since the effects of the irregularities of the canal bottom are more evident.

Nimnim and Farhan (2015) presented that the roughness coefficient also varies due to the bottom slope of the channel. That is why they varied the flow rate and the bottom slope of trapezoidal and semicircular canals, which were built in the laboratory. The slopes tested were $0.002,0.003$ and $0.004 \mathrm{~m} / \mathrm{m}$. For each slope, the flow rate varied between 2 and $10 \mathrm{~L} / \mathrm{s}$, obtaining the variation of the roughness coefficient, which was always around $5 \%$ for the three slopes, that is, the differences between the roughnesses for the flows of 2 to $10 \mathrm{~L} / \mathrm{s}$ were approximately $5 \%$.

Due to the importance and the difficulty in determining the roughness coefficient, several authors presented equations to quantify this value, which are presented in the specialized literature. Prajapati, Vadher and Yadav (2016) found roughness coefficients using Manning's Equation, the empirical relations of Limerinous, Strickler, Meyer-Peter and Muller and from the Cowan table. The results were compared to the value observed at the Garudeshwar station in the Purna River, in India. They concluded that the roughness coefficient calculated through Manning's equation is the one closest to the one observed, with an error of almost zero percent.

In the literature, there are softwares that calculate the roughness coefficient from the Manning equation. One of them is the program Canal (PRUSKI et al., 2006), which was developed by the Research Group on Water Resources of the Federal University of Viçosa (UFV, 2018), and used in this work, as will be explained in the following item.
In addition to the classical methods, in the present days, some authors have proposed other means to determine the roughness coefficient. Mtamba et al. (2015) used Radarsat-2 and Landsat TM for spatial estimation of Manning's roughness coefficient. Using the FLO-2D hydrodynamic model, the authors compared the water level found when using the roughness coefficient obtained with field information, to the one obtained using the roughness estimated from images, being that the two methods presented similar results.

However, even with the recent and old methodologies, uncertainties remain in estimating the roughness coefficient, since methods were developed according to local characteristics and may not fit other situations. Therefore, it is important that research at local levels, as proposed here, continue to be developed, in order to assist in hydraulic modeling. Therefore, several authors researched the behavior of the local roughness coefficient.

Zink and Jennings (2014) estimated the roughness coefficient in mountain rivers in North Carolina. Fard, Heidarnejad and Zohrabi (2013) determined an equation for the roughness coefficient of the Karum River. Parhi, Sankhua and Roy (2012) calibrated the value of the Manning coefficient to the Mahanadi River through flood simulation using the Hydrologic Engineering Center's River Analysis System (HEC-RAS). Matos et al. (2011) based their research on theoretical and practical studies to determine the roughness coefficient of the Sapucaí River in Minas Gerais. Lyra et al. (2010) determined the roughness coefficient for the Paracatu River as a function of the geometric characteristics of the channel and the series of daily flow rates from river stations existing along the river.

Other authors besides estimating the Manning's coefficient, also promoted discussion about the uncertainty associated to it. Kim, Kim and Woo (1995) presented the range of the Han River roughness coefficient and showed that a $20 \%$ change in its value can cause the calculated flood peak to vary by up to $10 \%$. Kim et al. (2010) show that due to errors of measuring water flow and water depth, the estimated roughness coefficient based on field data presents uncertainties. Using the Monte Carlo simulation, the authors determined the variation of the roughness coefficient when there is a variation of 5 and $10 \%$ in the flow rate, with a roughness variation of 6 to $14 \%$. In addition, for the roughness values obtained via Monte Carlo, they observed how this uncertainty impacts the values of estimated depths, obtaining a variation of approximately 2 to $4 \%$. Golshan, Jahanshahi and Afzali (2016) defined the flood areas for the return periods of 2, 5, 10, 25, 50, 100 and 200 years for the Safarood drainage basin, using HEC-RAS. By doubling the value of the roughness coefficient, the authors obtained that, for the periods of return from 2 to 200 years, the flood zone increased by $8.8 \%$ to $15.7 \%$, respectively.

A river of great importance in the national scenario is the Doce, also, there are several hydroelectric projects, from which, at the moment, four of them are hydroelectric plants (UHE) of greater size, and there are plans to install three more. It occurs that during the design and operation phases of these UHEs, numerical modeling is necessary for predictions of the behavior of the water line and the silting process of the reservoir. For cities with flooding problems, hydraulic simulations are also needed, such as those by CPRM (2004) and Coutinho (2015), which simulated 
flood spots for parts of the Doce River located in Governador Valadares-MG and Colatina-ES, respectively.

To implement these modelings one of the necessary input parameters is the Manning coefficient. However, there are no studies in the literature that have proposed to study the range of values and the behavior of Manning for this river. Therefore, studies such as the one proposed here are needed, so it can assist in future hydraulic simulations. The objective of this article is, therefore, to estimate the Manning's roughness along the Doce River, in order to compose a database that can help in future hydraulic simulations. In addition, it is discussed how the uncertainties in the Manning value can influence the final result of a hydraulic simulation, being also presented the spatio-temporal variations that occur with this coefficient.

\section{MATERIAL AND METHODS}

\section{Study area}

The Doce River drainage basin covers a total of 230 municipalities, in which more than 3.5 million inhabitants live. It has a drainage area of approximately $83,400 \mathrm{~km}^{2}$, with $86 \%$ of the basin being in Minas Gerais (MG) and 14\% in the state of Espírito Santo (ES) (CBH-DOCE, 2013). Located between the parallels $17^{\circ} 45$ 'and $21^{\circ} 15^{\prime} \mathrm{S}$ and the meridians $39^{\circ} 30^{\prime}$ ' and $43^{\circ} 45^{\prime} \mathrm{W}$, the basin integrates the hydrographic region of the Southeast Atlantic.

Its main river is the Doce, and its springs are found in the mountains of Mantiqueira and Espinhaço, in MG. Its formation takes place through the meeting of the Piranga River with Ribeirão do Carmo. It is approximately $850 \mathrm{~km}$ long and flows into the Atlantic Ocean, in Regência, ES (CBH-DOCE, 2013).

A characteristic that allows the determination of the values of Manning for the Doce River is the fact that, along the river, there are river flow stations that have historical series with the necessary data for the calculation of this coefficient. As described next, seven stations were used, which are distributed along the extension of $525 \mathrm{~km}$ of the river.

\section{Determination of Manning's roughness along the Doce River}

When making hydraulic simulations, the values of the Manning's roughness coefficient " $n$ " are required. Therefore, in order to estimate these values along the Doce River, the river flow stations that presented data series of cross-section, daily "Q" flows and water level quotas were surveyed on the HidroWeb website of the National Water Agency (ANA), and from the differences between the water levels and the smallest quotas of each cross section, the water depths "y" were obtained. Seven stations were found, which are presented in Table 1 and in Figure 1.

Table 1 shows the drainage area (A) for the seven river flow stations, the distances between one station and the next, the number of cross sections of each station, the period comprised of the measurements and the average slope.

The cross sections were surveyed only one time per year, not necessarily every year, which explains why section numbers differ between stations and why they are different from the number of years in the analyzed period. For example, for the station 56920000 there are cross section profiles comprised between 1990 and 2014 (Table 1). However, in this period only six sections were surveyed, which are from 1990, 1996, 2011, 2012, 2013 and 2014.

It should be emphasized that there is no specific month to carry out the surveys, so, there are cross sections obtained for months that vary from April to November, and there is no station that has a cross section profile surveyed from December to March, which are the main months for floods.

As done in Lyra et al. (2010) and Golshan, Jahanshahi and Afzali (2016), the slope of the water line was considered approximate to the slope "I" of the bottom of the river. According to CBH-DOCE (2005), the approximate mean slopes of the main channel of the river are $0.00075 \mathrm{~m} / \mathrm{m}$ at the high, $0.00059 \mathrm{~m} / \mathrm{m}$ at the medium and $0.00026 \mathrm{~m} / \mathrm{m}$ at the low Doce. These slopes were attributed to the stretches where the cross sections presented in Table 1 are, according to the location of the station.

For each cross section profile and the values of "Q" and " $y$ " measured on the day of the section survey, the values of " $n$ " were calculated using the Manning equation, with the assistance of the software Canal. Thus, for each river flow station an amount of " $n$ " values equal to the number of cross sections was obtained.

The software Canal uses the Manning equation (Equation 1) for the design of open channels. One must enter the slope of the river stretch, the coordinates of the cross-sections of interest, and, from the water depth value informed to the software, it calculates the wetted area and perimeter of the section. The flow rate should also be inserted, so that the only unknown in Manning's equation will be the roughness coefficient. The great advantage of using this software is that it calculates wetted areas and perimeters of irregular cross sections and that no iterative process for determining " $n$ " is needed, as in other softwares, such as HEC-RAS. Further details on the software Canal can be found in Pruski et al. (2006).

Table 1. River flow stations with bathymetry of cross sections.

\begin{tabular}{|c|c|c|c|c|c|}
\hline $\begin{array}{l}\text { Station } \\
\end{array}$ & $\mathrm{A}\left(\mathrm{km}^{2}\right)$ & Dist. $(\mathrm{km})$ & $\mathbf{N}^{\circ}$ of section & Time frame & $I(\mathrm{~m} / \mathrm{m})$ \\
\hline Faz. Cachoeira D'Antas (56425000) & 10100 & - & 17 & $1995-2014$ & 0.00075 \\
\hline Cachoeira dos Óculos (56539000) & 15900 & 35 & 14 & $1990-2016$ & \\
\hline Belo Oriente (56719998) & 24200 & 69 & 14 & $1993-2015$ & 0.00059 \\
\hline Governador Valadares (56850000) & 40500 & 72 & 8 & $1990-2012$ & \\
\hline Tumiritinga (56920000) & 55100 & 69 & 6 & $1990-2014$ & \\
\hline Resplendor (56948005) & 61200 & 123 & 7 & $1990-2004$ & \\
\hline Colatina $(56994500)$ & 76400 & 157 & 15 & $1990-2016$ & 0.00026 \\
\hline
\end{tabular}




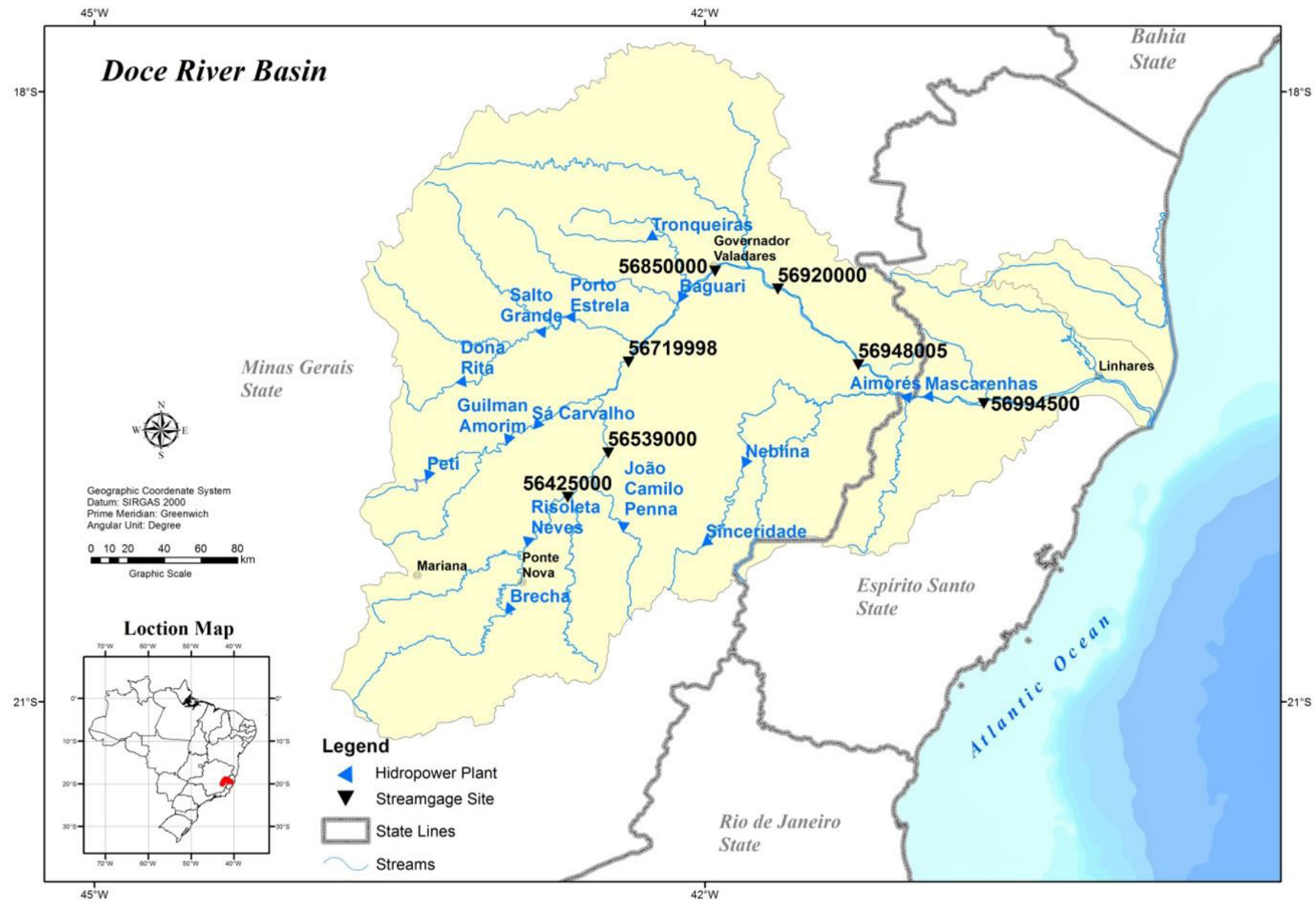

Figure 1. Hydroelectric plants and river stations of the Doce River used to determine the Manning coefficient.

$$
Q=A R^{2 / 3} \frac{I^{1 / 2}}{n}
$$

where: "Q" is the flow rate $\left(\mathrm{m}^{3} / \mathrm{s}\right)$, "A" is the Flow Area of the cross section $\left(\mathrm{m}^{2}\right)$, " $\mathrm{R}$ " is the Hydraulic Radius (m), " $\mathrm{I}$ " is the bottom slope of the Doce River $(\mathrm{m} / \mathrm{m})$ and " $n$ " is Manning's Roughness Coefficient, which value may vary between the main bed and the floodplain, so it has been assumed here that the value found is equivalent for the whole cross section.

\section{Relation between water depth and Manning's Coefficient}

As presented by Chow (1959), there are several interferers in the value of " $n$ ". However, in this work, only the interference of the water depth (y) variation in the Manning value was studied, since no other local data was available, such as vegetation, temporal variation of the slope of the water line and alteration of the bed by erosion and/or deposition of sediment. In order to verify the relation between these two variables, using the Canal software, values of " $y$ " were varied and " $n$ " were calculated, and for each " $y$ " its corresponding flow rate was used. This procedure was done for all cross sections of all seven river flow stations, shown in Table 1.
However, before performing the procedure described in the previous paragraph, it was verified whether there were significant differences in the values of " $\mathrm{n}$ " when they were calculated using two different procedures. In the first one, during the month in which the bathymetry of the cross section was surveyed, the daily values of " $y$ " and "Q" were varied and, for each pair of these values, the respective " $n$ " was calculated, finding, later, an average for these Manning $\left(\mathrm{n}_{\text {dail }}\right)$. In the second, for the month referring to the bathymetry of the cross-section, only one Manning value $\left(\mathrm{n}_{\text {monthly }}\right)$ was found, which was obtained from the average " $\mathrm{y}$ " and "Q" values of the month in question. The two procedures were done for all sections of all river flow stations. Thus, for each station, a set of " $n_{\text {daily }}$ " values and another of " $n_{\text {monthly }}$ " was obtained, the sizes of these sets being equal to the number of cross sections surveyed in the station. The verification of whether there was a significant difference between the two sets was made by applying Student's t-test to two means at a significance level of $5 \%$.

One of the premises of this test is that the dataset being tested follows Normal distribution. Therefore, the Shapiro-Wilk test, at $5 \%$ of significance, was used for each set of the station to verify the normality of the " $n$ " data.

As described in the results, there was no significant difference between the two ways of finding the monthly " $n$ " value. That is, by obtaining the values of " $n$ " using daily data of " $y$ " and " $Q$ " and then comparing them to the values of " $n$ " obtained by monthly 
"y" and "Q", the difference was not significant. Thus, the second procedure was chosen $\left(\mathrm{n}_{\text {monthly }}\right)$.

As a consequence of the large floods, which degrade the river bed and of the low flows, which allow the deposition of solid materials, it is possible that a cross section can change from one year to the next or during the same hydrological year. However, as there were not various cross-sections per year, since, as previously shown, only one annual survey occurs, it was assumed that the cross section remained unchanged throughout a hydrological year, which was defined, for the Doce River, as being between October and September of the following year, and this definition was made observing the data of the historical series of daily flow rates of the stations used.

For the monthly mean values of " $y$ " and "Q", the value of " $n$ " was calculated using the software Canal, so that 12 " $n$ " values were calculated for each cross section of each river flow station. In the end, since there are a total of 83 cross-sections (Table 1) and 12 values of " $n$ " for each section, there were 996 " $n$ " values.

The ratio between " $y$ " and " $n$ " was then graphically observed, as seen in Figure 2b (in the Results item). For this, the values of " $n$ " and " $y$ " of each cross section were plotted to verify the behavior during a hydrological year, being this procedure done for the 83 sections, that is, 83 graphs " $y$ " versus " $n$ " were constructed.

Posteriorly, for the sections of each river flow station, we found an average annual " $n$ " value (mean of the monthly " $n$ ") and the average annual " $y$ ". These values were plotted into a graph (as shown in Figure 3, in the Results item), in order to verify the behavior between the two variables over several years. Thus, seven graphs were constructed, one for each of the seven stations, and the number of points in each graph represent the number of cross sections of the station.

\section{Uncertainties associated with Manning coefficient values}

Once the roughness coefficient has effects on the analysis of the flow of a river, such as for predicting the water level during the floods, it was analyzed how errors in the measurements of "Q" flows and water depths " $y$ " can vary the values found for " $n$ ". Furthermore, it has been verified that this variation of " $n$ " can interfere with the value of " $y$ " in a hydraulic simulation.

The uncertainty analysis was done for three fluviometric stations, one in each region of the Doce River basin, Fazenda Cachoeira D'Antas (56425000) at the higher, Governador Valadares (56850000) at the medium and Colatina (56994500) at the lower Doce. For each of these stations, its more regular cross section was identified, so that the calculation of its wetted area and perimeter could be approximated to a regular geometry, such as the trapezoidal. This was necessary because of the calculation routine created in a spreadsheet, since thousands of " $n$ " values were generated, as described next, a very irregular cross section would increase the degree of difficulty of the calculations. The dimensions of the trapezoidal sections were established in such a way that the areas and the wetted perimeters found for this regular section were practically the same as the real ones, being these areas and perimeters referring to the depths and the flow rates shown in Table 2.

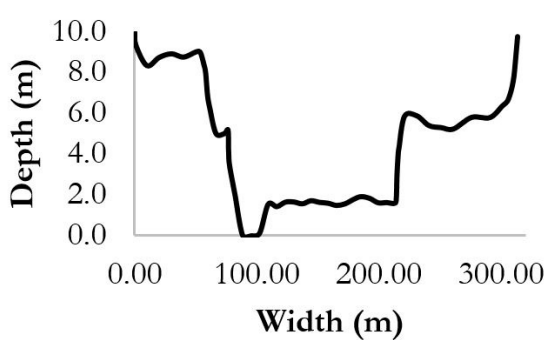

(a)

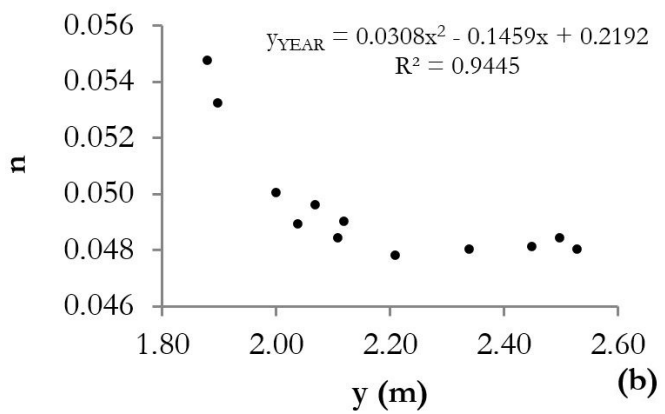

Figure 2. (a) Cross section of the year 2014 of Fazenda Cachoeira D'Antas station; (b) Relation between " $n$ " and " $y$ " for the hydrological year of 2014 .

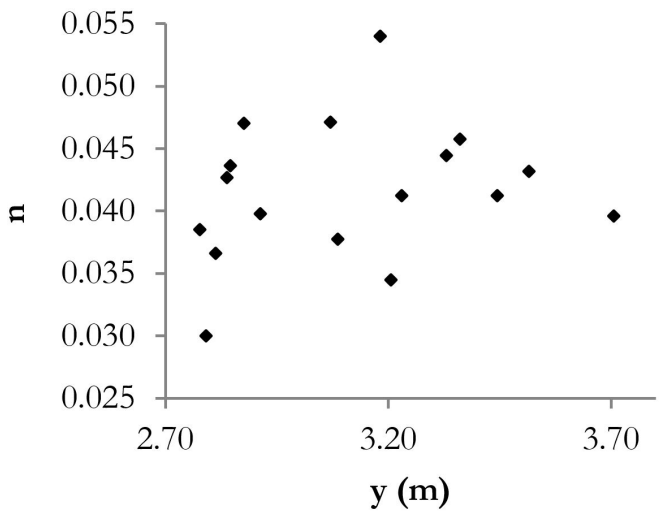

Figure 3. Relation between " $n$ " and " $y$ " over the years for the station of Fazenda Cachoeira D'Antas.

Table 2. Flow rates and depths field-measured for three river flow stations of the Doce River.

\begin{tabular}{|c|c|c|c|}
\hline Station & Date & $\mathrm{Q}\left(\mathrm{m}^{3} / \mathrm{s}\right)$ & $\mathrm{y}(\mathrm{m})$ \\
\hline$(56425000)$ & $21 / 08 / 2015$ & 37.15 & 1.89 \\
\hline$(56850000)$ & $17 / 06 / 2012$ & 418.70 & 3.33 \\
\hline$(56994500)$ & $12 / 07 / 2011$ & 446.80 & 2.45 \\
\hline
\end{tabular}

For each of the three stations, for the day that the chosen cross-section was surveyed, the values of "Q" and " $y$ " were identified in their series of data obtained from in situ measurements campaigns, and the results are presented in Table 2.

Using the Monte Carlo Simulation (SMC), the uncertainties in the values of " $n$ " were evaluated for variations of 5 and $10 \%$ in the "Q" and " $y$ " values of each station, and these levels of uncertainties were assigned to possible inaccuracies in " $Q$ " and "y" measurements, as presented by Kim et al. (2010).

Assuming a Uniform distribution, that is, that the probability of making a measurement error is equal to any value within a range, 
1000 depth values were generated, which varied between the measured depth value (Table 2 ) and $\pm 5 \%$ of this value, and another 1000 values varying between the measured value and $\pm 10 \%$ of this value, being this procedure done for the three stations. For example, for station 56425000,1000 values were generated between $1.80 \mathrm{~m}$ and $1.98 \mathrm{~m}$ $(-5 \%$ and $+5 \%$ of $1.89 \mathrm{~m}$, respectively) and 1000 values between $1.70 \mathrm{~m}$ and $2.08 \mathrm{~m}(-10 \%$ and $+10 \%$ of $1.89 \mathrm{~m}$, respectively).

For the generation of "Q" values, the same procedure was used, that is, Uniform distribution was assumed and values ranging from $\pm 5 \%$ to $\pm 10 \%$ in the measured "Q" value were generated (Table 2). 1000 values of " $Q$ " were generated for each one of the generated " $y$ " values. Thus, for each percentage of variation $(5 \%$ and $10 \%)$, one million flow rates were generated (1000 flow rates times 1000 depths). This same amount of values was generated for the three stations studied.

Each time a " $y$ " was generated, 1000 values of "Q" were generated, and then a " $n$ " was calculated for each one, that is, 1000 values of " $n$ " were calculated for the generated " $y$ ", and in this calculation the regular cross section chosen for the station in question was used.

In the end, for each station, one million " $n$ " were generated, via SMC, for the uncertainty of $\pm 5 \%$ and one million to $\pm 10 \%$. Then, for each station, the mean, maximum and minimum of these values were found, and it was observed how much they deviated from the real " $n$ ", which was calculated from the data of "Q" and " $y$ " obtained in the field (Table 2). Using the deviations of the found " $\mathrm{n}$ ", and their respective cross-sections and " $Q$ " (Table 2), it was estimated how much these deviations can cause variations of " $y$ ".

\section{RESULTS AND DISCUSSIONS}

\section{Determination of Manning's roughness along the Doce River}

The values of " $n$ " found for the seven Doce River river flow stations, which had bathymetry of their cross sections, are presented in Figure 4. The medians of " $n$ " of each season, in the order as presented in Figure 4, were: A) Fazenda Cachoeira D'Antas (56425000) - 0.037; B) Cachoeira dos Óculos (56539000) - 0.045; C) Belo Oriente (56719998) - 0.049; D) Governador Valadares (56850000) - 0.085; E) Tumiritinga (56920000) - 0.046; F) Resplendor (56948005) - 0.049; G) Colatina (56994500) - 0.028.

It is observed that the values of " $n$ " undergo spatial variation, since the medians are not equal among the stations, with the median " $n$ " of stations A, B, C, E, F being between 0.037 and 0.049 (dashed lines in Figure 4). On the other hand, stations D and G, respectively, Governador Valadares and Colatina, are the ones that present more discrepant values.

This spatial variation of " $n$ " was also observed by Zink and Jennings (2014), who estimated values between 0.039 and 0.064 for five sections along a river in North Carolina, being those values in the order of magnitude of those found by Matos et al. (2011), who estimated values ranging from approximately 0.030 to 0.070 for 36 sections along the Sapucaí River.

In the river flow station of Governador Valadares, the median value of 0.085 was high, compared to the others. However, it is in the same order of magnitude as that obtained by CPRM (2004), which, for the definition of the floodplain of the city homonymous to the station, based on hydraulic modeling made in HEC-RAS, allowed maximum values between 0.060 and 0.080 in all the cross sections used in the simulations. As the bottom of all cross sections of this station is very irregular, this may be raising the value of " $n$ ".

For Colatina, the median value of 0.028 was lower than the other stations, but it is close to that obtained by Coutinho (2015), who simulated flood spots in the city of Colatina using HEC-RAS, and defined Manning values for sections of the main channel varying between 0.028 and 0.033 . As this section of the Doce River is very silted, with the roughness of the sand in the order of 0.016 , this may have caused a decrease in the value of " $n$ ".

Both the work of CPRM (2004) and Coutinho (2015) used HEC-RAS to calibrate the values of " $n$ ", being in the same order of magnitude as those obtained in this article. It is observed, then, that the methodology used in this study presented results compatible with the studies that used HEC-RAS to calibrate " $n$ ".

Figure 4 shows that, for the same river flow station, the variation of " $\mathrm{n}$ " occurs over time, which was also observed by Lyra et al. (2010) for the Paracatu River, and these authors showed that the roughness coefficients varied significantly among the seasons. Some stations, such as Belo Oriente $(C)$, presented large deviations from the values, whereas in Colatina $(G)$ all values found are close to the median. Thus, in a hydraulic modeling over a long period of time, care must be taken when adopting a single Manning for the entire modeling period.

\section{Relation between water depth and Manning coefficient}

Table 3 shows the p-value found when applying the Shapiro-Wilk test for the seven stations. It has been shown that all p-values were higher than 0.05 (level of significance), both for the

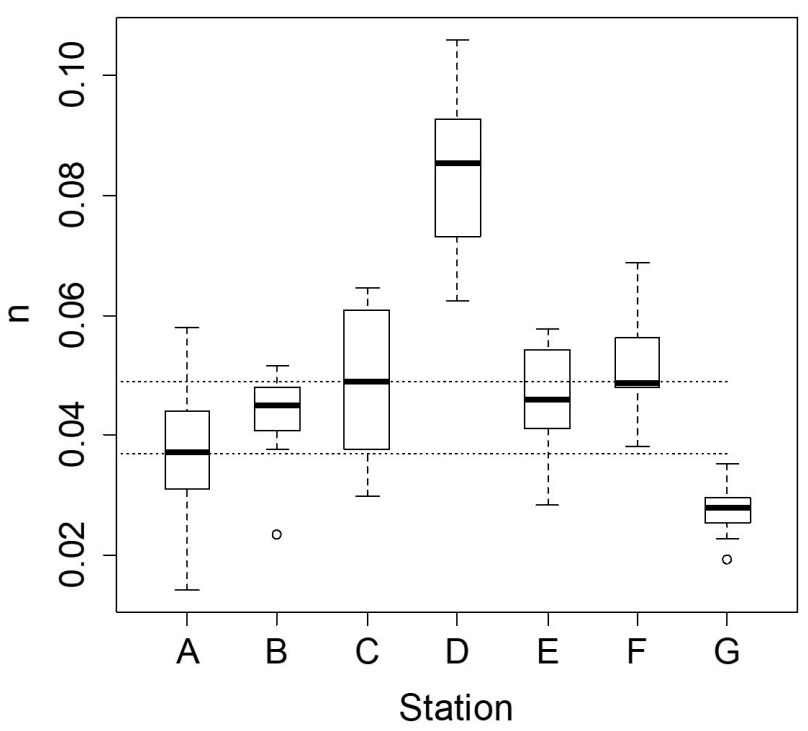

Figure 4. Spatio-temporal variation of Manning's roughness coefficients for seven river stations in Doce River. 
case where Manning $\left(\mathrm{n}_{\text {dail }}\right)$ was found using daily data of " $\mathrm{y}$ " and "Q", as for the case where we worked with monthly mean values of " $y$ " and " $Q$ " to calculate Manning ( $\left.\mathrm{n}_{\text {monthly }}\right)$. Thus, the two sets with values of " $n$ " follow Normal distribution, following the premise for the use of Student's t-test. For example, for station 56425000 a $\mathrm{p}$-value of $0.52\left(\mathrm{n}_{\text {daily }}\right)$ was obtained for the set of Manning values found using daily data of " $y$ " and "Q" and $0.44\left(\mathrm{n}_{\text {monthly }}\right)$ for the set obtained from monthly mean values of " $y$ " and "Q". As these values are greater than the level of significance, it is known that these roughness coefficients are normally distributed.

Also in Table 3, there is no significant difference between the

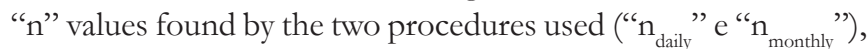
since all p-values found in the application of Student's t-test were greater than 0.05 . For example, for station 56425000 , the " $n$ " values found by the two procedures were 0.0421 and 0.0427 , and since the p-value was 0.16 (Table 3 ), statistically there was no difference between them.

Table 4 shows the behavior of the variation of " $n$ " (for each station) due to the variation of " $y$ " along the hydrological year of each cross section. For example, for station 56425000 , of the 19 cross-sections analyzed, it is found that by varying " $y$ " and calculating " $\mathrm{n}$ ", in 17 profiles the relation between these variables was directly proportional, while in two it was inversely proportional. It can be observed that for most stations there is not only one behavior, that is, in some sections the relation between these variables was directly proportional throughout the year, corroborating with Lyra et al. (2010), while in others it was inversely proportional, as observed by Zink and Jennings (2014), Fathi and Drikvandi (2012), Matos et al. (2011), Kim et al.

Table 3. p-values for the applied statistical tests.

\begin{tabular}{ccccc}
\hline \multirow{2}{*}{ Station } & \multicolumn{2}{c}{ Shapiro-Wilk } & & $\begin{array}{c}\text { Student's } \\
\text { T-test }\end{array}$ \\
\cline { 2 - 3 } & \multicolumn{2}{c}{$\boldsymbol{p}$-value } & & p-value \\
\cline { 2 - 3 } & $\mathbf{n}_{\text {daily }}$ & $\mathbf{n}_{\text {monthly }}$ & \\
\hline 56425000 & 0.52 & 0.44 & & 0.16 \\
56539000 & 0.69 & 0.73 & \\
56719998 & 0.36 & 0.45 & 0.38 \\
56850000 & 0.86 & 0.88 & 0.18 \\
56920000 & 0.52 & 0.44 & 0.17 \\
56948005 & 0.71 & 0.69 & 0.35 \\
56994500 & 0.86 & 0.97 & 0.32 \\
\hline
\end{tabular}

Table 4. Relation between the variation of Manning coefficient and water depth.

\begin{tabular}{cccc}
\hline \multirow{2}{*}{ Station } & \multicolumn{3}{c}{ Number of Sections } \\
\cline { 2 - 4 } & $\begin{array}{c}\text { Directly } \\
\text { proportional }\end{array}$ & $\begin{array}{c}\text { Inversely } \\
\text { proportional }\end{array}$ & $\begin{array}{c}\text { Low } \\
\text { correlation }\end{array}$ \\
\hline 56425000 & 17 & 2 & - \\
56539000 & 13 & - & 1 \\
56719998 & 4 & 6 & 4 \\
56850000 & - & 8 & - \\
56920000 & 3 & 2 & 1 \\
56948005 & - & 6 & 1 \\
56994500 & 7 & 4 & 4 \\
\hline
\end{tabular}

(2010) and Chow (1959). There were also sections where it was not possible to observe any correlation between the two variables.

One explanation for not having a single rule for the relation between these two variables is the cross section format and the range of " $y$ " in this section. Observing the relation between these variables, for each cross section of each station, it was noticed that when the section tends to have two defined beds, one bigger and one smaller, the relation between the variables tends to be directly proportional when the flow occurs in the higher bed and inversely proportional when the flow is at the lowest, as expected. This happens because the larger bed may be the floodplain, where there are several materials, such as vegetation, gravel, among others, which increases the value of Manning (PARSAIE et al., 2017). While in the lower bed, where consequently the flow has a lower depth, the effects of canal bottom irregularities are more evident, which increases Manning's value (CHOW, 1959).

An example that illustrates the previous assertion is in Figure 2, where it is presented in (a) the cross section of the year 2014 of the river flow station Fazenda Cachoeira D'Antas (56425000). In Figure 2b is the curve representing the variation between " $n$ " and " $y$ " along the hydrological year of 2014 and also the regression equation of this curve is presented. It is observed in Figure $2 \mathrm{a}$ that for depths smaller than approximately $2.00 \mathrm{~m}$ the flow is in the smaller channel of the river. In Figure $2 b$, it is observed that for " $y$ " up to approximately $2.20 \mathrm{~m}$, the variation of " $\mathrm{n}$ " is inversely proportional to " $y$ ", while for " $y$ " the relation becomes directly proportional. In general, in other stations the behavior was the same occurred in Fazenda Cachoeira D'Antas.

Observing Table 4, it can be noted that only in the Governador Valadares (56850000) and Resplendor (56948005) stations the relation between " $n$ " and " $y$ " was always inversely proportional, and the possible reason for this to happen is the fact that all the cross sections of these stations do not clearly show the existence of two beds, as observed in Figure 2a.

For each station, when all the annual mean values of " $n$ " and their respective annual " $y$ " values were plotted, it was observed that in none of them there was correlation between these variables over the years. Figure 3 shows the behavior between these variables for Fazenda Cachoeira D'Antas station (56425000), which represents the other stations, since the behavior is the same, and the number of points in the graph indicates the number of cross sections that existed for the station, that is, each point is an annual average " $n$ " and " $y$ " value of a section.

It is noticed that there is no possibility of only one equation to relate these variables, since it cannot explain the behavior of " $n$ " over the years. One reason for such a random behavior between " $n$ " and " $y$ " is the fact that the constant change of the cross-sections, as shown in Figure 5, in which is presented the change occurred in the cross section between the years of 2013 and 2014, in the station Fazenda Cachoeira D'Antas (56425000). It is noteworthy that this change in the cross sections occurred for the seven river flow stations studied. Thus, the roughness of a given year has no correlation with that of a subsequent year and/or later.

In order to confirm the lack of autocorrelation between the values of " $n$ " over the years, the correlogram (Figure 6) was constructed for the roughness of Fazenda Cachoeira D'Antas, which was presented in Figure 3. In this correlogram, it is noted that there is no significant autocorrelation (ACF) for any Lag, since they are all within the limits of confidence (dashed lines). 


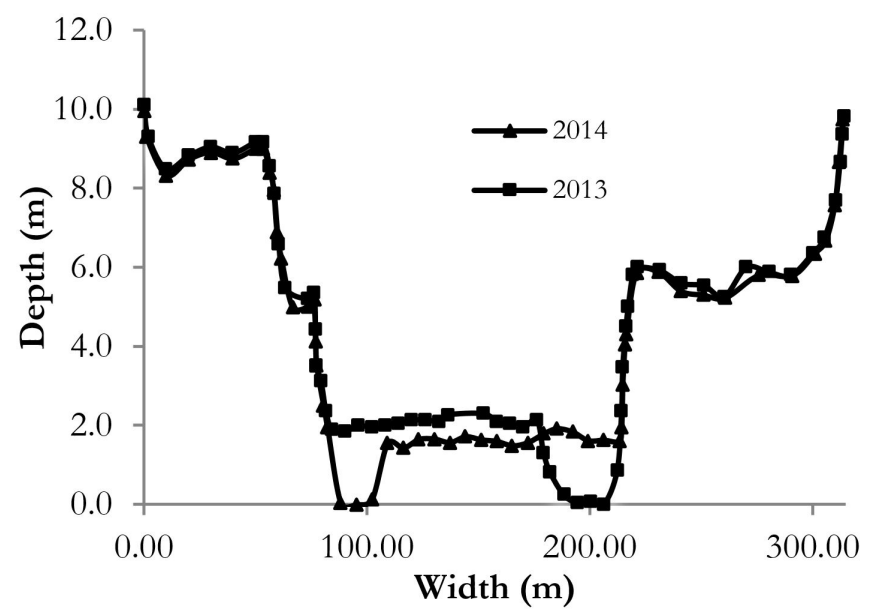

Figure 5. Alteration of the cross section of Fazenda Cachoeira D'Antas between the years of 2013 and 2014.

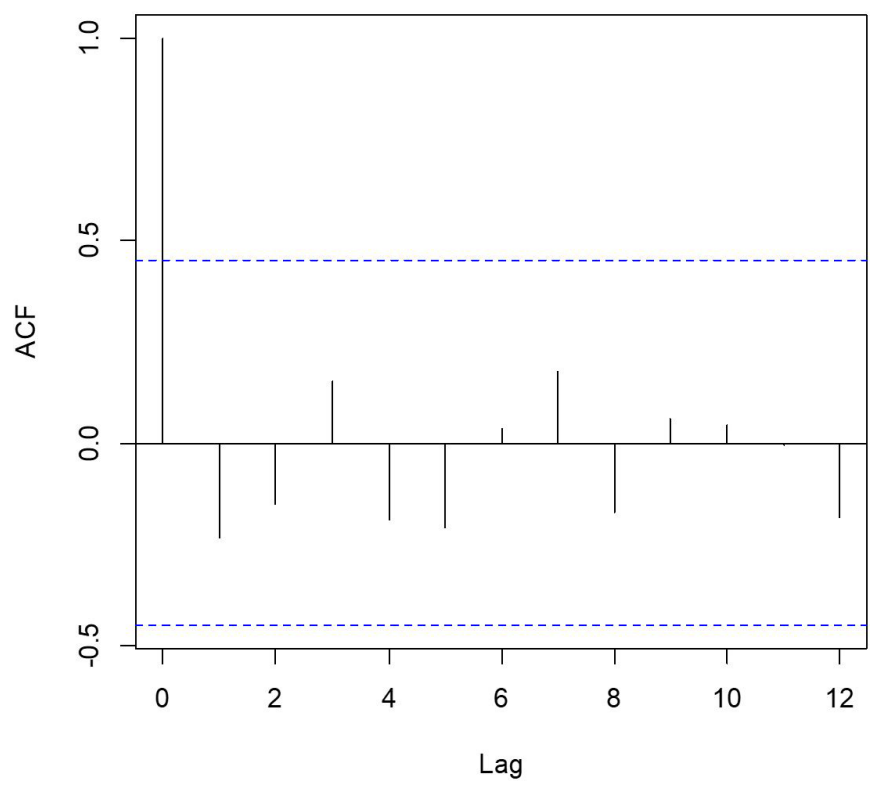

Figure 6. Correlogram for the average annual roughness of Fazenda Cachoeira D'Antas.

\section{Uncertainties associated with Manning coefficient values}

Figures 7 to 9 show the values of " $n$ " generated from the Monte Carlo Simulation (SMC). The dashed lines indicate the quartiles of probability, being the $25 \%$ quartile the first line and the $75 \%$ quartile the second. Although the values of flows and depths, which originated the values of " $n$ ", follow the Uniform distribution, it can be seen from the figures that " $n$ " does not tend to follow the same probability distribution.

Table 5 shows the uncertainties associated with the values of " $n$ " due to errors of \pm 5 and $\pm 10 \%$ in the flow rate measurement $\left(\mathrm{Q}_{\text {real }}\right)$ and depth $\left(\mathrm{y}_{\text {rea }}\right)$. Considering as the correct Manning $\left(\mathrm{n}_{\text {real }}\right)$ the one calculated from the data measured in the field, which are recorded in the historical series of the stations, it is observed that an error of $\pm 5 \%$ causes the greatest uncertainty,
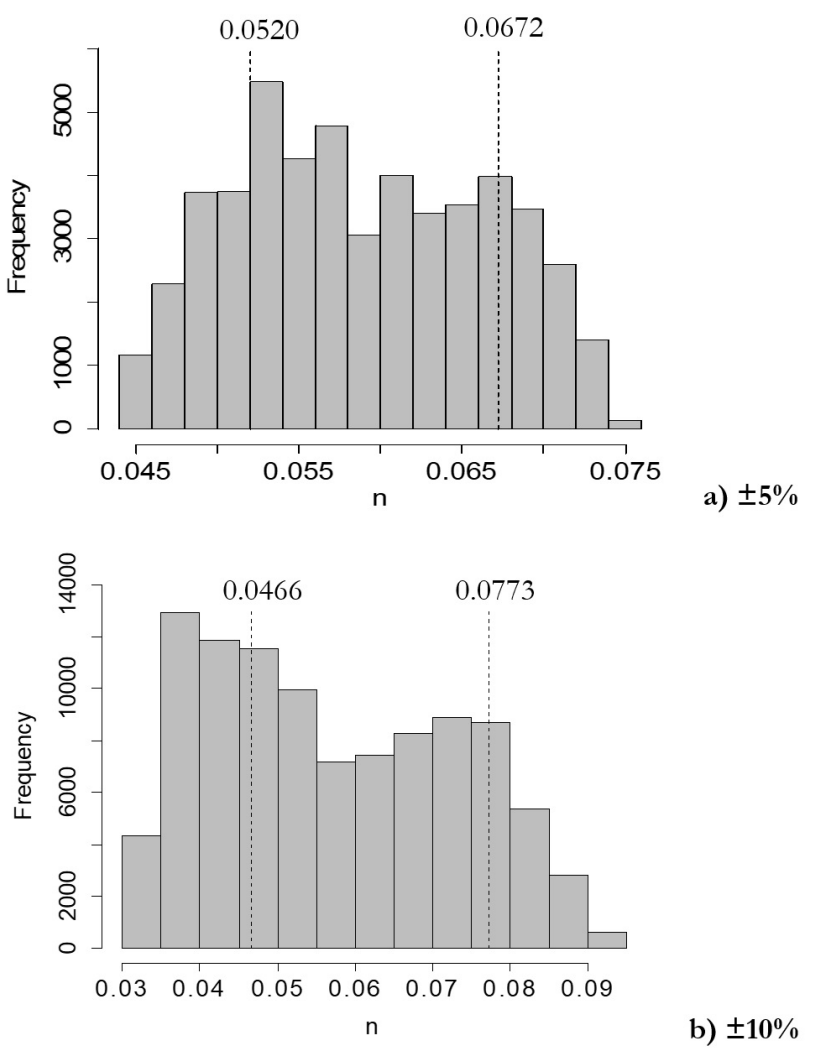

Figure 7. Manning's Roughness coefficient via SMC for Fazenda Cachoeira D'Antas.
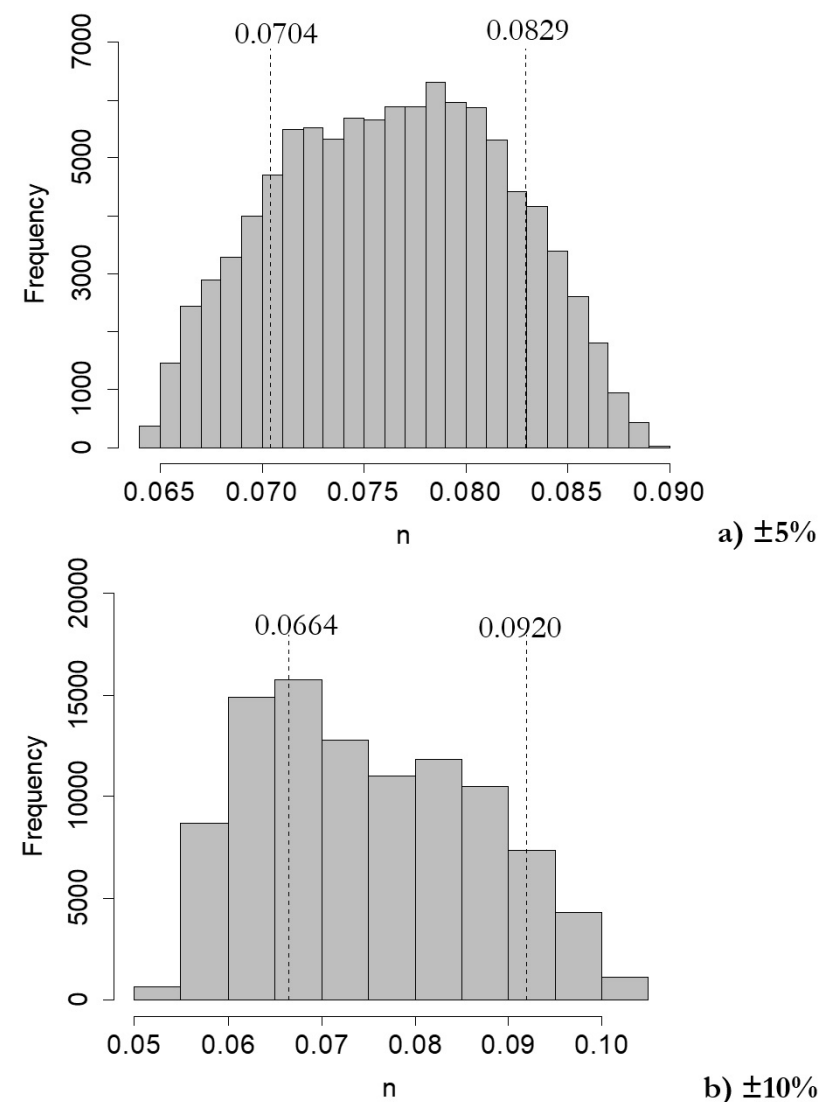

b) $\pm 10 \%$

Figure 8. Manning's Roughness coefficient via SMC for Governador Valadares station (56850000). 
of $1.72 \%$, in the value of the average " $n$ " of Fazenda Cachoeira D'Antas station (56425000) and the lowest uncertainty of $0.99 \%$ for Governador Valadares (56850000). For an error of $\pm 10 \%$, the highest uncertainty for the mean " $\mathrm{n}$ " is $1.72 \%$ for Colatina (56994500) and the lowest, of 1.01\%, for Governador Valadares (56850000).
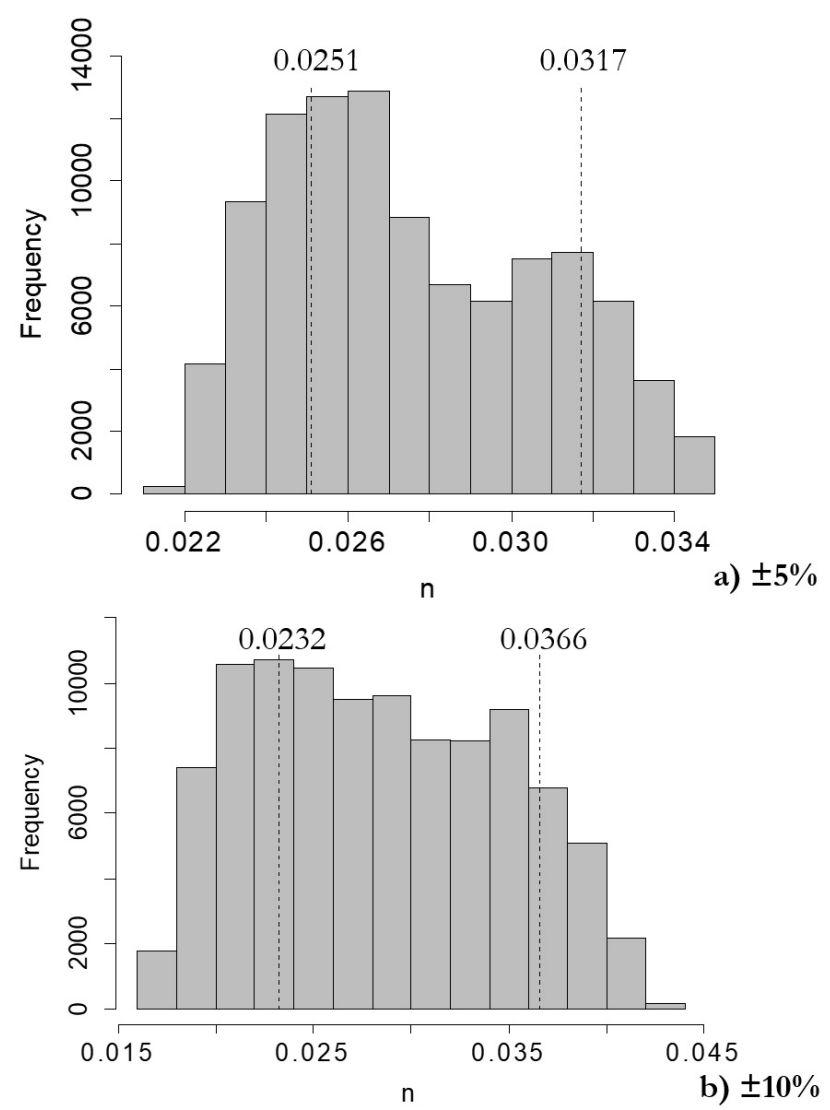

Figure 9. Manning's Roughness coefficient via SMC for Colatina station (56994500).
When comparing the "n "real "with the maximum " $n$ " values obtained, for $\pm 5 \%$ of variation, it is noticed that the greatest uncertainty occurs in the Fazenda Cachoeira D'Antas station (56425000), where the maximum value found (0.0748) deviates from the real value $(0.0579)$ in $29.21 \%$. For $\pm 10 \%$ variation, the highest uncertainty occurs at the same station, where the difference between the maximum value (0.0927) and the real value (0.0579) was $60.06 \%$.

In the case of comparing the " $\mathrm{n}_{\text {real }}$ " with the minimum " $n$ " values, for $\pm 5 \%$ of variation, the greatest uncertainty was obtained for Fazenda Cachoeira D'Antas station (56425000), since the difference between the minimum value found (0.0444) and the real value $(0.0579)$ was $23.23 \%$. For $\pm 10 \%$, again the greatest uncertainty, which was $46.05 \%$, occurred at Fazenda Cachoeira D'Antas station (56425000).

Thereby, it can be seen that the greatest uncertainties, both for the maximum and the minimum, were for the station with the lowest flow rate and depth, corresponding to Fazenda Cachoeira D'Antas, showing that errors in low values of "Q" and " $y$ " may cause greater uncertainties in the " $n$ " values.

Table 6 shows the values of " $y$ " obtained from the Manning coefficients generated by SMC (maximum, average and minimum presented in Table 5). It is also shown how much these "y" distanced themselves from the depth (yreal) measured in the field.

For \pm 5 and $\pm 10 \%$, using the average " $n$ " value generated by SMC to simulate the values of " $y$ ", in Table 6 , it is noticed that the largest error in the calculated " $y$ " was for the station of Colatina (56994500), when the variation was $\pm 5 \%$, and this error was $5.51 \%$. The lowest error was $0.37 \%$ for a variation of $\pm 5 \%$ in Fazenda Cachoeira D'Antas station (56425000). Kim et al. (2010) found maximum error of $4.2 \%$ in the value of " $y$ ", for $10 \%$ of variation, and minimum of $2.3 \%$, for $5 \%$ of variation. Thus, it is observed that even if there are uncertainties in the mean " $n$ " values, the impact caused by the " $y$ " value was small for the stations studied. It should be noted that the Doce River tends to have wide channels along it, as in the case of the three

Table 5. Uncertainties associated to the values of the Manning coefficient due to errors of \pm 5 and $\pm 10 \%$ in the flow values of depths measured in the field.

\begin{tabular}{|c|c|c|c|c|c|c|c|c|c|c|}
\hline \multirow{2}{*}{ Station } & \multirow{2}{*}{$\begin{array}{c}Q_{\text {real }} \\
\left(\mathrm{m}^{3} / \mathrm{s}\right)\end{array}$} & \multirow{2}{*}{$\mathrm{y}_{\text {real }}(\mathrm{m})$} & \multirow{2}{*}{$\begin{array}{c}\text { Error } \\
(\%)\end{array}$} & \multicolumn{3}{|c|}{$\mathbf{n}$} & \multirow{2}{*}{$\mathbf{n}_{\text {real }}$} & \multicolumn{3}{|c|}{ Uncertainties of $n(\%)$} \\
\hline & & & & $\operatorname{Max}$ & Average & Min & & Max & Average & Min \\
\hline \multirow[t]{2}{*}{$(56425000)$} & 37.15 & 1.89 & 5 & 0.0748 & 0.0589 & 0.0444 & 0.0579 & 29.21 & 1.72 & 23.23 \\
\hline & & & 10 & 0.0927 & 0.0590 & 0.0312 & & 60.06 & 1.38 & 46.05 \\
\hline \multirow[t]{2}{*}{$(56850000)$} & 418.7 & 3.33 & 5 & 0.0891 & 0.0764 & 0.0642 & 0.0757 & 17.65 & 0.99 & 15.19 \\
\hline & & & 10 & 0.1047 & 0.0749 & 0.0537 & & 38.30 & 1.01 & 29.04 \\
\hline \multirow[t]{2}{*}{$(56994500)$} & 446.8 & 2.45 & 5 & 0.0349 & 0.0275 & 0.0217 & 0.0279 & 25.28 & 1.29 & 21.99 \\
\hline & & & 10 & 0.0432 & 0.0283 & 0.0166 & & 54.75 & 1.72 & 40.52 \\
\hline
\end{tabular}

Table 6. Uncertainties associated to the simulated depths with the values of " $\mathrm{n}$ " obtained via SMC.

\begin{tabular}{|c|c|c|c|c|c|c|c|c|}
\hline \multirow{2}{*}{ Station } & \multirow{2}{*}{$\mathrm{y}_{\text {real }}(\mathrm{m})$} & \multirow{2}{*}{ Error (\%) } & \multicolumn{3}{|c|}{$\mathrm{y}$} & \multicolumn{3}{|c|}{ Error of y $(\%)$} \\
\hline & & & Max & Average & Min & Max & Average & Min \\
\hline \multirow[t]{2}{*}{$(56425000)$} & 1.89 & 5 & 2.01 & 1.90 & 1.78 & 6.30 & 0.37 & 5.66 \\
\hline & & 10 & 2.12 & 1.90 & 1.67 & 12.38 & 0.42 & 11.90 \\
\hline \multirow[t]{2}{*}{$(56850000)$} & 3.33 & 5 & 3.57 & 3.34 & 3.11 & 7.27 & 0.39 & 6.70 \\
\hline & & 10 & 3.84 & 3.32 & 2.89 & 15.23 & 0.45 & 13.21 \\
\hline \multirow[t]{2}{*}{$(56994500)$} & 2.45 & 5 & 2.50 & 2.32 & 2.15 & 2.08 & 5.51 & 12.41 \\
\hline & & 10 & 2.69 & 2.34 & 1.97 & 9.59 & 4.61 & 19.63 \\
\hline
\end{tabular}


stations studied, so that the variation of " $y$ " is small, and in case of narrow channels the uncertainty in the value of " $n$ " may cause greater variation in the simulated " $y$ " value.

When the extreme values of " $\mathrm{n}$ " (maximum and minimum of Table 5) were used to calculate "y", it was obtained that the simulated depths were more distant from the real ones. When using the maximum " $n$ " from Table 6 , it is noticed that the largest error in the simulated " $y$ " value was $15.23 \%$ in the Governador Valadares station (56850000), for a variation of $\pm 10 \%$, being this error the difference between the simulated depth, $3.84 \mathrm{~m}$, and the actual depth, $3.33 \mathrm{~m}$. In regarding to the minimum " $\mathrm{n}$ ", the simulated depth of $1.97 \mathrm{~m}$ was the most distant from the real one, $2.45 \mathrm{~m}$, a fact observed in the Colatina station (56994500), being this error of $19.63 \%$ obtained for the variation of $\pm 10 \%$. It is observed, then, that the extreme " $n$ " caused a maximum variation of $\pm 0.5 \mathrm{~m}$ in the water depth. Again, it is emphasized that in narrow channels the variation in water depth may be greater.

\section{CONCLUSION}

Manning's roughness coefficients were estimated for seven river flow stations installed along the Doce River. From these values, we have that:

- The Manning coefficient values undergo spatial-temporal variation along the Doce River, and the median values for the stations Fazenda Cachoeira D'Antas (56425000), Cachoeira dos Óculos (56539000), Belo Oriente (56719998), Tumiritinga (56920000) and Resplendor (56948005) are within the same range of values. On the other hand, the stations Governador Valadares (56850000) and Colatina (56994500) present median values that differ from the others. However, it should be noted that the median values of " $n$ " of the stations may not represent the period of maximum river flow rates, since, as presented in the methodology, in no station there was a determined cross section profile in the rainy season, so that the Manning values that were found are all referring to the flow rates between April and November. Because the Manning values undergo temporal variation, it is suggested that hydraulic models, for the Doce River, can be made separated by shorter periods of time, so that each period uses a different Manning coefficient.

- There is not a single relation between Manning's values and water depth, which means that there are cases in which this relation is directly and other cases in which it is inversely proportional, for the same station. This is due to the shape of the cross section, being that when there are two beds, a bigger and a smaller one, the tendency is that the relation between these variables is inversely proportional in the smaller bed and directly proportional in the larger one. Thus, for the Doce River, attention should be paid when using some equation from literature that relates exclusively water depth to the Manning coefficient, since this relation is variable in time.

- The historical series of flow rates and water levels were known, however, this does not mean that there are not inaccuracies in their values. As these series were used for determining the roughness, inaccuracies in the " $\mathrm{n}$ " values could consequently occur. Thus, these uncertainties were analyzed. For this, three river stations were studied, one for each region of the Doce River, and it was obtained that errors of \pm 5 and $\pm 10 \%$ in the value of the flow rate and of water depth originated low percentages of uncertainties in the average values of Manning. However, there were extreme point values (maximums and minimums) that distanced themselves more from the real value of Manning. When using the average values of " $n$ " to simulate depth values, the simulated " $y$ " values were close to those measured in the field, ie, this average value of " $n$ " had little effect on the final result of the waterline simulations. However, this conclusion can not be extended to all hydrodynamic models, since only one model was evaluated in this work (Canal software), which uses the Manning Equation to simulate flow depths. When " $y$ " was simulated using extreme " $n$ " values, a greater variation was obtained between the simulated and the real " $y$ ", with a maximum variation of $\pm 0.5 \mathrm{~m}$. However, it is noteworthy that the cross sections of the three stations were broad, and in narrower sections, which have greater water depth variation, the uncertainties in the Manning values may cause greater variation in the simulated depths.

Recently, the Doce River was highlighted because of everything that involved the dam collapse in Mariana (the position of this city in the Doce River basin is presented in Figure 1), which culminated in a large volume of tailings thrown into the river. Because of this, in some places the roughness coefficient may have been affected, since the mining tailings, which have a specific weight greater than that of water, deposited at many points, changing the material and shape of the cross-section. However, the cross sections topographies of immediately after the tailings passage were not available, so that, in this work, the influence of these tailings in the value of Manning was not analyzed. Thus, it is recommended to continue this study in order to evaluate the probable changes in the Manning coefficients due to the dam rupture in Mariana.

In the analysis of uncertainties, the influence of inaccuracies in the slope of the sections in the value of the roughness coefficient was not evaluated, so that this should be done in future works, in order to continue the verification of the behavior of the Manning coefficient of the Doce River.

\section{ACKNOWLEDGEMENTS}

To the Federal University of São João del-Rei for financial support and the postgraduate program in Sanitation, Environment and Water Resources of the Federal University of Minas Gerais.

\section{REFERENCES}

AYVAZ, M. T. A linked simulation-optimization model for simultaneously estimating the Manning's surface roughness values and their parameter structures in shallow water flows. Journal of Hydrology, v. 500, p. 183-199, 2013. http://dx.doi.org/10.1016/j. jhydrol.2013.07.019. 
CALO, V. M.; COLLIER, N.; GEHRE, M.; JIN, B.; RADWAN, H.; SANTILLANA, M. Gradient-based estimation of Manning's friction coefficient from noisy data. Journal of Computational and Applied Mathematics, v. 238, p. 1-13, 2013. http://dx.doi.org/10.1016/j. cam.2012.08.004.

CBH-DOCE - COMITÊ DA BACIA HIDROGRÁFICA DO RIO DOCE. Diagnóstico consolidado da bacia do Rio Doce. Governador Valadares: CBH-DOCE, 2005.

CBH-DOCE - COMITÊ DA BACIA HIDROGRÁFICA DO RIO DOCE. Plano Integrado de Recursos Hídricos da Bacia do Rio Doce (PIRH). Governador Valadares: CBH-DOCE, 2013.

CHOW, V. T. Open channel bydraulics. New York: McGraw-Hill, 1959.

COUTINHO, M. M. Avaliação do desempenho da modelagem hidráulica unidimensional e bidimensional na simulação de eventos de inundação em Colatina/ES. 2015. 245 f. Dissertação (Mestrado em Saneamento, Meio Ambiente e Recursos Hídricos) - Escola de Engenharia, Universidade Federal de Minas Gerais, Belo Horizonte, 2015.

CPRM - SERVIÇO GEOLÓGICO DO BRASIL. Definição da planície de inundação da cidade de Governador Valadares: relatório técnico final. Belo Horizonte: CPRM, 2004. p. 128.

FARD, R. S.; HEIDARNEJAD, M.; ZOHRABI, N. Study factors influencing the hydraulic roughness coefficient of the Karun river (Iran). International Journal of Farming and Allied Sciences, v. 22, n. 2, p. 976-981, 2013.

FATHI, M. M.; DRIKVANDI, K. Manning roughness coefficient for rivers and flood plains with non-submerged vegetation. International Journal of Hydraulic Engineering, v. 1, n. 1, p. 1-4, 2012.

GOLSHAN, M.; JAHANSHAHI, A.; AFZALI, A. Flood hazard zoning using HEC-RAS in GIS environment and impact of manning roughness coefficient changes on flood zones in Semiarid climate. Desert, v. 21, n. 1, p. 24-34, 2016.

KIM, J. S.; LEE, C. J.; KIM, W.; KIM, Y. J. Roughness coefficient and its uncertainty in gravel-bed river. Water Science and Engineering, v. 3 , n. 2 , p. $217-232,2010$.

KIM, W.; KIM, Y. S.; WOO, H. S. Estimation of channel roughness coefficients in the Han river using unsteady flow model. Hangug Sujaweon Haghoe Nonmunjib, v. 28, n. 6, p. 133-146, 1995.

KIM, Y.; TACHIKAWA, Y.; SHIIBA, M.; KIM, S.; YOROZU, K.; NOH, S. J. Simultaneous estimation of inflow and channel roughness using $2 \mathrm{D}$ hydraulic model and particle filters. Journal of Flood Risk Management, v. 6, n. 2, p. 112-123, 2013. http://dx.doi. org/10.1111/j.1753-318X.2012.01164.x.

KOPECKI, I.; SCHNEIDER, M.; TUHTAN, J. A. Depthdependent hydraulic roughness and its impact on the assessment of hydropeaking. The Science of the Total Environment, v. 575, n. 1, p. 1597-1605, 2017. http://dx.doi.org/10.1016/j.scitotenv.2016.10.110. PMid:27802885.

LYRA, G. B.; CECÍLIO, R. A.; ZANETTTI, S. S.; LYRA, G. B. Coeficiente de rugosidade de Manning para o Rio Paracatu. Revista Brasileira de Engenharia Agrícola e Ambiental, v. 14, n. 4, p. 343-350, 2010. http://dx.doi.org/10.1590/S1415-43662010000400001.

MATOS, A. J. S.; PIOLTINE, A.; MAUAD, F. F.; BARBOSA, A. A. Metodologia para a caracterização do coeficiente de Manning variando na seção transversal e ao longo do canal. Estudo de caso bacia do Alto Sapucaí-MG. RBRH: Revista Brasileira de Recursos Hídricos, v. 16, n. 4, p. 21-28, 2011. http://dx.doi.org/10.21168/ rbrh.v16n4.p21-28.

MTAMBA, J.; VAN DER VELDE, R.; NDOMBA, P.; ZOLTÁN, V.; MTALO, F. Use of Radarsat-2 and Landsat tm images for spatial parameterization of Manning's roughness coefficient in hydraulic modeling. Remote Sensing, v. 7, n. 1, p. 836-864, 2015. http://dx.doi.org/10.3390/rs70100836.

NIMNIM, H. T.; FARHAN, B. A. Evaluation of Manning's coefficient of ferrocement trapezoidal and semicircle canals strengthened by CFRP sheets. International Journal of Energy and Environment, v. 6, n. 5, p. 461-470, 2015.

PARHI, P. K.; SANKHUA, R. N.; ROY, G. P. Calibration of channel roughness for Mahanadi River (India), using HEC-RAS model. Journal of Water Resource and Protection, v. 4, n. 10, p. 847-850, 2012. http://dx.doi.org/10.4236/jwarp.2012.410098.

PARSAIE, A.; NAJAFIAN, S.; OMID, M. H.; YONESI, H. Stage discharge prediction in heterogeneous compound open channel roughness. Journal of Hydraulic Engineering, v. 23, n. 1, p. 49-56, 2017. http://dx.doi.org/10.1080/09715010.2016.1235471.

PRAJAPATI, P. R.; VADHER, B. M.; YADAV, S. M. Comparative analysis of hydraulic roughness coefficient at Purna River sites. Global Research and Development Journal for Engineering, v. 1, n. 4, p. 574-579, 2016.

PRUSKI, F. F.; SILVA, D. D.; TEIXEIRA, A.; CECÍLIO, R. A.; SILVA, J. M. A.; GRIEBELER, N. P. Hidros: dimensionamento de sistema hidroagrícolas. Viçosa: Editora UFV, 2006. 259 p.

UFV - UNIVERSIDADE FEDERAL DE VIÇOSA. Grupo de Pesquisa em Recursos Hídricos. Softwares. Viçosa: UFV, 2018. Disponível em: <http://www.gprh.ufv.br/?area=softwares $>$. Acesso em: 31 jan. 2018.

ZINK, J. M.; JENNINGS, G. D. Channel roughness in North Carolina mountain streams. Journal of the American Water Resources Association, v. 50, n. 5, p. 1354-1358, 2014. 


\section{Authors contributions}

Emmanuel Kennedy da Costa Teixeira: Work creator. Executor of all work steps and article text writer.

Márcia Maria Lara Pinto Coelho: PhD advisor of the first author of this paper. Guiding all stages of the work. Revision of the text of the article.
Eber José de Andrade Pinto: Guiding all stages of the work. Reviewer of the text of the article.

Jéssica Guimarães Diniz: Executing the work. He effectively participated in the tabulation of the thousands of data, as well as the simulations of the data made in the hydraulic program.

Aloysio Portugal Maia Saliba: Participated in the conception of the methodology of the article and in the discussion of the results achieved. Reviewer of the text of the article. 